\title{
PENGARUH SENAM NIFAS TERHADAP PENURUNAN TINGGI FUNDUS UTERI (TFU) PADA IBU POSTPARTUM NORMAL DI WILAYAH KERJA PUSKESMAS PRABUMULIH BARAT
}

\author{
Intan Sari \\ Akademi Kebidanan Budi Mulia Prabumulih
}

\author{
A B S T R A K
}

Informasi Artikel :

Diterima : April 2018

Disetujui : Mei 2018

Dipublikasikan : Juni 2018

\author{
*Korespondensi Penulis : \\ Intannadhifa215@gmail.com
}

Perdarahan postpartum terjadi setelah kelahiran bayi “ sebelum, selama dan sesudah keluarnya plasenta. Masa nifas adalah masa sesudah persalinan dan kelahiran bayi, plasenta, serta selaput yang diperlukan untuk memulihkan kembali organ kandungan seperti sebelum hamil dengan waktu kurang lebih 6 minggu. Senam nifas adalah senam yang dilakukan ibu-ibu setelah melahirkan setelah keadaan tubuhnya pulih kembali. Senam nifas bertujuan untuk mempercepat penyembuhan, mencegah timbulnya komplikasi, memulihkan dan menguatkan otot-otot punggung, otot dasar panggul dan otot perut. Penelitian ini bertujuan untuk mengetahui pengaruh senam nifas terhadap kecepatan penurunan Tinggi Fundus Uteri (TFU). Penelitian ini dilakukan di Wilayah Kerja Puskesmas Prabumulih Barat. Penelitian ini menggunakan metode penelitian eksperimen yaitu untuk mencari pengaruh perlakuan tertentu terhadap yang lain dalam kondisi yang terkendalikan dengan jumlah responden 15 ibu nifas. Dari penelitian didapatkan hasil U hitung sebesar 40 yang lebih kecil bila dibanding $U$ tabel sebesar 56 dan nilai $p$ value 0.001 yang lebih kecil bila dibanding nilai $\alpha=0.05$ sehingga hipotesis di terima yaitu ada pengaruh senam nifas terhadap penurunan TFU pada ibu post partum di Wilayah Kerja Puskesmas Prabumulih Barat. Mengingat besarnya manfaat yang diperoleh ibu post partum, bila melaksanakan senam nifas maka diharapkan institusi pelayanan kesehatan menerapkan senam nifas sebagai asuhan pada ibu post partum.

Kata Kunci : : Senam nifas, involusi uteri

\section{ABSTRACT}

Postpartum haemorrhage occurs after the birth of the baby "before, during and after placental discharge. The postpartum period is the period after childbirth and the birth of the baby, placenta, and the membranes necessary to restore the pregnant organs such as before pregnancy in about 6 weeks. Postpartum gymnastics is a gymnastics performed by mothers after giving birth after the condition of his body recovered. Postural gymnastics aims to speed healing, prevent complications, restore and strengthen the back muscles, pelvic floor muscles and abdominal muscles. This study aims to determine the effect of puerperal gymnastics on the rate of decrease in High Fundus Uteri (TFU). This research was conducted in Prabumulih Barat Health Center Working Area. This research uses experimental research method that is to find the effect of certain treatment to others in controlled condition with the number of respondents 15 postpartum. From the research results obtained $U$ calculate of 40 smaller when compared to table $U$ of 56 and value of $p$ value 0.001 smaller than the value of $\alpha=0.05$ so that the hypothesis is accepted that there is influence of puerperal gymnastics on the decrease of TFU in post partum mother in Work Area Puskesmas Prabumulih Barat. Given the magnitude of the benefits of postpartum mothers, when implementing gymnastics gymnastics it is expected that health care institutions apply gymnastics exercises as care for post partum mothers. 


\section{PENDAHULUAN}

Perdarahan postpartum terjadi setelah kelahiran bayi " sebelum, selama dan sesudah keluarnya plasenta. Menurut definisi, hilangnya darah lebih dari $500 \mathrm{ml}$ selama 24 jam pertama merupakan perdarahan postpartum. Setelah 24 jam, keadaan ini dinamakan perdarahan postpartum lanjut atau Late Postpartum Hemorrhage. (Oxorn dan William R.Forte, 2010).

Masa nifas adalah masa sesudah persalinan dan kelahiran bayi, plasenta, serta selaput yang diperlukan untuk memulihkan kembali organ kandungan seperti sebelum hamil dengan waktu kurang lebih 6 minggu (Pitriani Risa,2014).

Upaya Departemen Kesehatan (Depkes) untuk mempercepat penurunan AKI adalah dengan mendekatkan pelayanan kebidanan pada setiap ibu, sehingga sehingga diharapkan setiap ibu mendapat akses terhadap pelayanan kebidanan. Untuk itu penting adanya standar pelayanan kebidanan dalam meningkatkan kualitas pelayanan kebidanan, termasuk standar pelayanan nifas meliputi pelaksanaan, pemeliharaan dan peningkatan kualitas pelayanan. Bidan memberikan pelayanan selama nifas melalui kunjungan rumah pada 24 jam pertama, hari ke-3, hari ke-6, minggu ke-2 dan minggu ke-6 setelah persalinan untuk membantu proses pemulihan ibu.(Depkes RI, 2005).

Normalnya, sejak hari pertama melahirkan secara alami sampai waktu 40 hari, ibu akan mengalami periode masa nifas (perdarahan sisasisa dari proses persalinan). Pada minggu pertama masa nifas, darah yang keluar berwarna merah segar (Lochia Rubra). Setelah itu selama dua minggu, warna darah yang keluar berubah menjadi kecokelatan dan kekuningan (Lochia Sanguinolenta). Berikutnya, mulai keluar lendirlendir putih bening atau agak kuning (lochia alba). Masih berkaitan dengan itu, hari kedua atau ketiga setelah melahirkan, selain ASI mulai keluar, ibu juga akan mengalami kontraksi-kontraksi kuat yang berdampak terhadap mengecilnya rahim kembali ke ukuran sebelum hamil.(Ipoel, 2017).

Senam nifas adalah senam yang dilakukan ibu-ibu setelah melahirkan setelah keadaan tubuhnya pulih kembali. Senam nifas bertujuan untuk mempercepat penyembuhan, mencegah timbulnya komplikasi, memulihkan dan menguatkan otot-otot punggung, otot dasar panggul dan otot perut.

Pada saat hamil otot perut dan sekitar rahim serta vagina telah teregang dan melemah. Latihan senam nifas dilakukan untuk membantu mengencangkan otot-otot tersebut. Hal ini untuk mencegah terjadinya nyeri punggung dikemudian hari dan terjadinya kelemahan pada otot panggul sehingga dapat mengakibatkan ibu tidak bisa menahan BAK. Gerakan senam nifas dilakukan dari gerakan yang paling sederhana hingga yang tersulit. (Rini Susilo, 2016).

Bidan diharapkan dapat memberikan asuhan dan pelayanan kebidanan selama periode postpartum, mencakup pemenuhan kebutuhan ibu selama masa nifas, untuk itu penting mengembangan standar pelayanan kebidanan untuk meningkatkan kualitas pelayanan kebidanan. Berdasarkan perubahan fisiologi selama kehamilan, maka perlu dilaksanakan latihan selama post partum dengan latihan rutin dan bertahap sesuai kemampuan fisik, sebagai bentuk upaya preventif dan promotif. (Tapiwa, 2001).

Proses Pemulihan organ reproduksi pada masa nifas merupakan hal yang sangat penting. Hal inilah yang mendasari kebutuhan untuk melakukan observasi Tinggi Fundus Uteri (TFU) dan derajat kontraksi uterus. Uterus yang berkontraksi dengan baik secara bertahap akan berkurang ukurannya, sampai tidak dapat dipalpasi lagi diatas simpisis pubis. Kondisi ini tentunya tidak terlepas dari perubahan fisiologi yang luar biasa terjadi selama kehamilan. Diantara faktor yang berperan dalam kontraksi uterus adalah kadar $\mathrm{Hb}$, kadar kalsium, volume intrauterin, menyusui dan senam nifas. Senam nifas sebagai salah satu upaya untuk meningkatkan kontraksi uterus masa post partum, maka ibu post partum didorong untuk melakukan senam nifas dalam rangka mempercepat proses involusi uterus.(Varney, 2007).

Penelitian Nurtiati dkk, 2014. Mengatakan bahwa terdapat perbedaan yang signifikan penurunan tinggi fundus uteri antara kedua kelompok pada hari ke-3 $(p=0,00)$ dan hari ke 6 $(p=0,00)$ sehingga didapatkan hasil penelitian senam nifas berpengaruh terhadap penurunan tinggi fundus uteri. Penurunan tinggi fundus uteri pada kelompok intervensi lebih turun dibanding kelompok kontrol.

Penelitian ini bertujuan untuk mengetahui pengaruh senam nifas terhadap kecepatan penurunan Tinggi Fundus Uteri (TFU) di Wilayah Kerja Puskesmas Prabumulih Barat

\section{METODE PENELITIAN}

Penelitian eksperimen merupakan metode penelitian yang digunakan untuk mencari pengaruh perlakuan tertentu terhadap yang lain dalam kondisi yang terkendalikan (Sugiyono, 2007). Desain atau rancangan dalam penelitian ini menggunakan rancangan eksperimen semu (quasi experiment design). Dalam rancangan penelitian 
ini sampel dibagi menjadi dua kelompok, yaitu kelompok kontrol dan kelompok perlakuan (Notoadmojo, 2010). Pemilihan kedua kelompok ini menggunakan teknik acak (Nursalam 2003).

Populasi dalam penelitian ini adalah keseluruhan ibu multipara postpartum yang memenuhi kriteria di Wilayah Kerja Puskesmas Prabumulih Barat selama 1 bulan terakhir yaitu sebanyak 41 ibu nifas.

Sampel adalah sebagian atau wakil populasi yang diteliti. Di dalam penelitian ini, sampel ditentukan dengan kriteria inklusi, yaitu karakteristik umum subjek peneliti dari suatu populasi target yang terjangkau yang akan diteliti.

Adapun kriteria inklusi dari penelitian ini adalah :

1. Bersedia menjadi responden

2. Ibu postpartum normal pervaginam

3. Ibu postpartum hari ke $1-10$

4. Menyusui bayinya

Sedangkan kriteria eksklusi sampel dalam penelitian ini adalah :

1. Tidak bersedia menjadi responden

2. Berusia $<20$ tahun dan atau $>35$ tahun

3. Melahirkan anak $>4$ anak

Tehnik pengambilan sampel adalah dengan tehnik accidental sampling, tehnik ini adalah tehnik penentuan sampel berdasarkan kebetulan, yaitu siapa saja yang secara kebetulan/insidental bertemu dengan peneliti dapat digunakan sebagai sample, bila dipandang orang yang kebetulan ditemui itu cocok sebagai sumber data (Sugiyono, 2007).

Dalam penelitian ini analisis univariat yang digunakan adalah distribusi frekuensi. Analisis ini dilakukan dengan tujuan untuk menggambarkan tiap variabel yang diteliti secara terpisah dengan cara membuat tabel distribusi frekuensi dan proporsi dari masing-masing variabel yaitu :

a. Penurunan TFU pada ibu post partum normal yang dilakukan senam nifas.

b. Penurunan TFU pada ibu post partum normal yang tidak dilakukan senam nifas.

Analisis Bivariat yang dilakukan terhadap dua variabel yang diduga berhubungan atau berkolerasi (Notoatmojo, 2010). Dalam penelitian ini, analisis yang digunakan untuk mengetahui perbedaan percepatan penurunan TFU antara ibu postpartum yang diberikan perlakuan senam nifas dan yang tidak diberikan perlakuan senam nifas. Uji yang dilakukan adalah uji statistik Mann-
Whitney karena variabel pengaruh memiliki skala ukur nominal sedangkan variabel terpengaruh memiliki skala ukur ordinal.

Dengan menggunakan uji Mann-Whitney U Test yang dibantu dengan komputer, hal ini sesuai dengan pendapat Sugiyono (2006), bahwa U-test ini digunakan untuk menguji hipotesis komparatif dua sampel indepeden bila datanya berbentuk ordinal. Terdapat dua rumus yang digunakan untuk mengetahui harga U mana yang lebih kecil. Harga U yang lebih kecil tersebut digunakan untuk pengujian dan membandingkan dengan $\mathrm{U}$ tabel.

Apabila $\mathrm{p}$ value $<\alpha$ dimana $\alpha=0,05$ maka hipotesis diterima yang berarti ada perbedaan kecepatan penurunan TFU antara ibu yang diberi perlakuan senam nifas dan tidak diberi perlakuan senam nifas, yang artinya senam nifas berpengaruh terhadap kecepatan penurunan TFU pada ibu post partum. Apabila $p$ value $>\alpha$ dimana $\alpha=0,05$ maka hipotesis ditolak yang berarti tidak ada pengaruh senam nifas terhadap kecepatan penurunan TFU pada ibu post partum.

\section{HASIL PENELITIAN}

\section{Gambaran Umum Responden}

Karakteristik Responden

Pada penelitian ini, karakteristik responden meliputi usia responden dan paritas responden. Dalam penelitian ini usia responden adalah ibu post partum yang berusia 20-35 tahun. Yang merupakan usia wanita yang paling produktif dan dianggap memiliki resiko paling rendah untuk kematian ibu. Sedangkan paritas responden adalah ibu post partum multipara yang memiliki paritas 2-4 anak dimana paritas ini dinilai sebagai paritas yang memiliki resiko paling rendah.

\section{Analisis Univariat}

a. Gambaran penurunan TFU pada Ibu Post Partum yang diberi perlakuan senam nifas

Tabel 1 Distribusi Frekuensi penurunan TFU pada ibu post partum normal yang diberi perlakuan senam nifas

\begin{tabular}{lll}
\hline \multicolumn{1}{c}{ Penurunan TFU } & Jumlah & Persentase \\
\hline Cepat & 7 & $46 \%$ \\
Normal & 6 & $40 \%$ \\
Lambat & 2 & $14 \%$ \\
\hline Total & 15 & $100 \%$ \\
\hline \multicolumn{2}{c}{ Berdasarkan tabel 1 di atas dapat } \\
diketahui sebagian responden yang diberi \\
perlakuan senam nifas, mengalami penurunan
\end{tabular}


TFU yang cepat yaitu sebanyak 7 orang (46\%), dan sebagian lainnya lain mengalami penurunan TFU yang normal yaitu sebanyak 6 orang $(40 \%)$ dan sebagian kecil lainnya mengalami penurunan TFU yang lambat yaitu sebanyak 2 orang (14\%).

b. Gambaran Penurunan TFU Pada Ibu Post Partum yang Tidak diberi Perlakuan Senam Nifas

Tabel 2 Distribusi Frekuensi penurunan TFU pada ibu post partum normal yang tidak diberi perlakuan senam nifas

\begin{tabular}{ccc}
\hline Penurunan TFU & Jumlah & Persentase \\
\hline Cepat & 1 & $7 \%$ \\
Normal & 5 & $33 \%$ \\
Lambat & 9 & $60 \%$ \\
\hline Total & 15 & $100 \%$ \\
\hline
\end{tabular}

Berdasarkan tabel 2 di atas dapat diketahui sangat sedikit responden den yang diberi perlakuan senam nifas, mengalami penurunan TFU yang cepat yaitu sebanyak 1 orang $(7 \%)$, dan sebagian kecil lain mengalami penurunan TFU yang normal yaitu sebanyak 5 orang (33\%) dan sebagian besar lainnya mengalami penurunan TFU yang lambat yaitu sebanyak 9 orang $(60 \%)$.

\section{Analisis Bivariat}

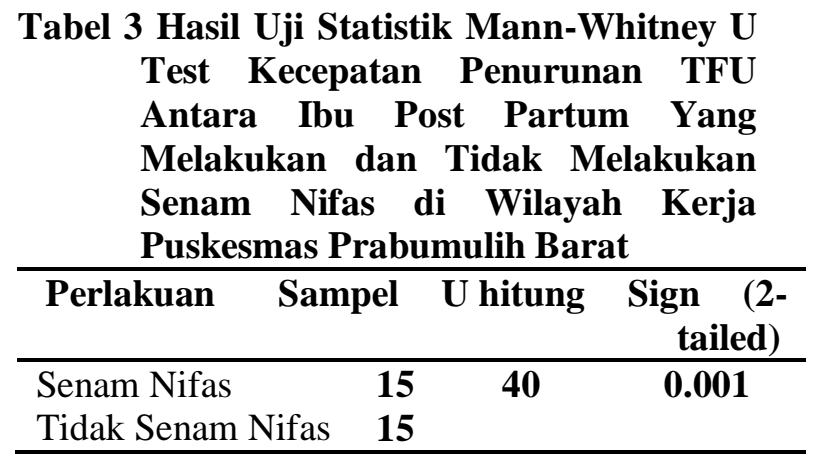

Dengan menggunakan Mann-Whitney U Test yang dibantu dengan mengolah data menggunakan program SPSS didapatkan U hitung sebesar 40 lebih kecil dibandingkan U tabel sebesar 56 dan nilai $p$ value sebesar 0.001 lebih kecil dari nilai $\alpha=0.05$ yang artinya ada perbedaan kecepatan penurunan TFU antara ibu postpartum yang diberi perlakuan senam nifas dan tidak diberikan perlakuan senam nifas sehingga hipotesis diterima yang berarti ada pengaruh senam nifas terhadap kecepatan penurunan TFU pada ibu post partum di Wilayah Kerja Puskesmas Prabumulih Barat.

\section{B. PEMBAHASAN}

1. Kecepatan penurunan TFU pada ibu post partum yang diberi perlakuan senam nifas

Pada Penelitian ini menunjukan sebagian responden yang diberi perlakuan senam nifas mengalami penurunan TFU yang lebih cepat yaitu sebanyak 7 orang (46\%), sebagian kecil lainnya mengalami penurunan TFU normal yaitu sebanyak 6 orang $(40 \%)$ dan 2 orang lainnya (14\%) mrngalami penurunan TFU lambat. Penurunan TFU dikatakan cepat apabila TFU sudah tidak teraba lagi sebelum hari ke 10, normal apabila TFU sudah tidak teraba tepat pada hari ke 10 dan dikatakan lambat apabila TFU sudah tidak teraba lagi setelah hari ke-10. Senam nifas mulai dilakukan pada hari pertama post partum setelah keadaan ibu memungkinkan yakni paling cepat 6 jam post partum, dilakukan 1 kali dalam sehari dan berakhir pada saat TFU sudah tidak dapat diraba lagi.

Selama masa nifas akan terjadi pemulihan organ reproduksi termasuk di dalamnya uterus. Setelah melahirkan uterus berangsur-angsur menjadi kecil sehingga akhirnya kembali ke keadaan seperti sebelum hamil. Segera setelah janin lahir, fundus uteri setinggi pusat, setelah plasenta lahir fundus uteri kira-kira setinggi 2 jari di bawah pusat. Dalam 2-4 jam setelah persalinan TFU meningkat $2 \mathrm{~cm}$ di atas pusat. Selanjutnya TFU menurun $1 \mathrm{~cm}$ ( 1 jari ) setiap harinya. Pada hari ke 5- 7 post partum TFU teraba pada pertengahan pusat dan symphisis dan tidak teraba lagi pada hari ke 10 (Ambarwati, 2010).

Setelah persalinan otot-otot uterus berkontraksi sehingga pembuluh darah yang ada pada rahim akan terjepit. Oleh karena itu apabila ibu postpartum melakukan mobilisasi segera setelah persalinan akan membantu meningkatkan kontraksi uterus dan mempercepat proses involusi uteri (Prawirohardjo, 2007).

Salamah, 2003 mengatakan bahwa umumnya para ibu pasca melahirkan takut melakukan banyak gerakan. Sang ibu biasa khawatir gerakan-gerakan yg dilakukan akan menimbulkan dampak yg tdk diinginkan. Padahal apabila ibu bersalin melakukan ambulasi dini itu bisa memperlancar terjadi proses involusi uteri. Salah satu aktivitas yg dianjurkan untuk dilakukan para ibu setelah persalinan adalah senam nifas (Salamah, 2003).

Menurur Suparyanto, 2010 Senam nifas merupakan salah satu bentuk aktifitas fisik yang dapat dilakukan oleh ibu post partum. Aktifitas fisik ini akan mempengaruhi kebutuhan otot- 
otot rahim dan dasar panggul terhadap oksigen dimana kebutuhannya akan meningkat yang berarti memerlukan aliran darah yang kuat, sehingga menyebabkan uterus berkontraksi, dengan berkontraksinya uterus mengakibatkan penurunan TFU lebih cepat dan pengeluaran lochea pun menjadi lebih lancar sebagai indikator terjadinya involusi uterus.

\section{Kecepatan Penurunan TFU Pada Ibu Post Partum Yang Tidak Diberi Perlakuan Senam Nifas.}

Pada penelitian ini dapat diketahui bahwa sebagian besar responden yang tidak diberi perlakuan senam nifas mengalami penurunan TFU yang lebih lambat yaitu sebanyak 9 orang (60\%) sedangkan yang mengalami kecepatan penurunan TFU yang cepat hanya 1 orang $(7 \%)$ dan 5 orang $(33 \%)$ lainnya mengalami kecpatan penurunan TFU yang normal.

Meskipun tidak melakukan senam nifas, ibu postpartum di Kawasan Kerja Puskesmas Ungaran tetap melakukan berbagai aktifitas fisik seperti miring ke kiri dan ke kanan, mengasuh bayi dengan memandikan, berjalanjalan antara ruangan di dalam rumah, dan lain sebagainya sehingga kontraksi uterus tetap dapat terjadi. Tetapi kecepatan penurunan TFU terjadi lebih lambat apabila dibandingkan dengan ibu yang melakukan latihan senam nifas. Dengan melakukan aktifitas fisik maka aliran darah akan menjadi semakin lancar dan kontraksi uterus akan menjadi semakin baik, sehingga akan mempengaruhi proses pengecilan uterus (Manuaba, 1998).

Setelah proses persalinan uterus ibu akan mengalami proses pengecilan yang disebut dengan involusi uterus mulai dari berat uterus 1000 gram hingga kembali ke ukuran sebelum hamil yaitu 60 gram. Setelah uterus kembali ke berat semula 60 gram maka sebagian orang berpendapat bahwa masa nifas telah selesai. Padahal selama masa nifas bukan hanya terjadi perubahan pada rahim, tetapi juga pada organ lainnya seperti perubahan gastrointestinal, system perkemihan, system musculoskeletal dan lain sebagainya yang secara keseluruhan akan memakan waktu sekitar 3 bulan lamanya (Anggraini, 2010).

Ibu post partum di Wilayah Kerja Puskesmas Prabumulih Barat pun menyusui bayinya, sehingga proses involusi uterus tetap terjadi karenan rangsangan isapan bayi pada saat menyusu akan menimbulkan rangsangan yang diteruskan ke hipofisis anterior yang selanjutnya akan merangsang pengeluaran hormone oksitosin. Melalui aliran darah hormone ini diangkut menuju uterus yang dapat menimbulkan kontraksi uterus sehingga akan terjadi proses involusi (Cunningham, 2006). Hal ini lah yang menyebabkan ibu postpartum yang tidak melakukan senam nifas tetap mengalami involusi uterus tetapi lebih lambat jika dibandingkan dengan ibu postpartum yang melakukan senam nifas.

Pada penelitian ini ibu postpartum memiliki jumlah paritas anak 2-4 anak yang merupakan paritas paling aman bila dilihat dari sudut pandang resiko kematian maternal dimana pada paritas ini proses kehamilan sampai masa nifas ibu jarang mengalami komplikasi(Sarwono, 2006). Selain itu pada paritas ini uterus juga masih belum terlalu teregang bila dibandingkan dengan ibu grandemultipara. Karena semakin sering seorang wanita hamil maka uterus wanita tersebut juga akan semakin sering mengalami peregangan. Karena itu . kondisi otot rahim pada ibu grandemultipara cenderung sudah tidak terlalu kuat maka proses involusi berjalan lebih lambat (Setyono,2010).

3. Pengaruh senam nifas terhadap kecepatan penurunan TFU pada ibu post partum yang diberi perlakuan senam nifas dan yang tidak diberi perlakuan senam nifas.

Hasil uji statistik dengan menggunakan rumus Mann-Whitney U Test menunjukan nilai U hitung sebesar 40 yang lebih kecil bila disbanding nilai $U$ tabel yang nilainya 56 dan nilai $\mathrm{p}$ value sebesar 0.001 yang lebih kecil dibanding nilai $\alpha=0.05$ sehingga $\mathrm{H} 0$ di tolak yang artinya ada pengaruh senam nifas terhadap kecepatan penurunan TFU pada ibu post partum.

Menurut Prawirohardjo (2007) selama kehamilan akan terjadi peregangan pada otototot uterus dan jaringan lain pada perut yang bertujuan memberikan ruang tumbuh untuk perkembangan janin intra uterin. Selain itu juga terjadi perubahan sikap dan bentuk tubuh sebagai bentuk adaptasi terhadap perbesaran uterus dan penambahan berat badan. Pada saat persalinan otot-otot dasar panggul mengalami peregangan dimana fungsi utama otot dasar panggul yaitu mempengaruhi efisiensi kandung kemih, menopang isis panggul dan mempengaruhi kenikmatan pada saat berhubungan seksual. Karenanya ibu post partum sangat perlu melakukan senam nifas 
guna mempercepat proses pemulihan otot-otot dasar panggul.

Anggraini, 2010 mengatakan Ibu post partum disarankan melakukan mobilisasi dini karena dapat memperlancar terjadinya proses involusi uteri (kembalinya rahim ke bentuk semula). Salah satu bentuk latihannya yaitu dengan melakukan senam nifas. Dalam perencanaan dan pelaksanaan senam nifas harus dilakukan secara bertahap, sistematik dan kontinyu. Dimana tujuan dilakukan senam nifas itu sendiri yaitu memperbaiki elastisitas otot yang telah mengalami peregangan, memperbaiki dan memperlancar sirkulasi darah dalam tubuh, dan memperlancar proses involusi uterus dan memperbaiki sikap tubuh setelah proses persalinan.

Menurut Ambarwati, 2010.Senam nifas memberikan bentuk latihan gerak secepat mungkin agar otot-otot yang mengalami peregangan selama proses persalinan kembali ke keadaan sebelum hamil. Setiap gerakan selama melakukan senam nifas memiliki tujuan yang spesifik yang akan membantu mempercepat proses involusi uterus. Misalnya pada latihan pernafasan iga-iga yang bertujuan meningkatkan asupan oksigen dan memperlancar sirkulasi udara. Latihan otot perut dan otot bokong bertujuan mengurangi resiko penyulit pada saat buang air besar maupun buang air kecil, mengurani rasa nyeri pada daerah luka jahitan serta membantuk kontraksi uterus sehingga proses involusi menjadi lebih cepat berakhir serta mengurangi rasa mulas.

Involusi uterus disebabkan oleh kontraksi dan retraksi serabut otot uterus yang terjadi secara terus menerus sehingga mengakibatkan kompresi pembuluh darah serta iskemia, atrofi yaitu jaringan berproliferasi dalam jumlah besar kemudian mengalami atrofi sebagai reaksi terhadap pemberhentian produksi estrogen yang terjadi saat plasenta lepas (Ambarwati, 2010).

Dilihat dari segi usia ibu post partum yang berada di Wilayah Kerja Puskesmas Prabumulih Barat memiliki usia 20-35 tahun dimana usia ini merupakan usia yang paling aman dan memiliki resiko kecil bila ditinjau dari segi kematian maternal. Pada usia ini pula otot uterus memiliki daya regang dan kekuatan yang lebih baik bila dibandingkan pada ibu post partum yang berusia di bawah 20 tahun atau di atas 35 tahun. Pada usia reproduksi ini masih belum terjadi peningkatan jumlah lemak, penurunan elastisitas otot, penyerapan lemak, protein serta karbohidrat yang abnormal sehingga pengecilan otot rahim setelah melahirkan tidak membutuhkan waktu yang terlalu lama. Dengan melakukan ambulasi dini dan senam nifas maka akan dapat meningkatkan dan membantu kontraksi serta retraksi serabut otot polos uterus sehingga proses involusi pun berlangsung lebih cepat.

Hasil penelitian ini sesuai dengan hasil penelitian yang dilakukan Yuniarti Tri Kurniati pada tahun 2009 di Puskesmas Margangsang Kota Yogyakarta dimana pada kelompok perlakuan proses involusinya berlangsung lebih cepat bila dibanding dengan ibu post partum pada kelompok kontrol yang tidak diberi perlakuan senam nifas, hanya yang membedakan disini adalah ibu post partum pada penelitian tersebut adalah ibu yang memiliki paritas 1 atau primipara.

\section{Kesimpulan}

Berdasarkan hasil penelitian dan pembahasan yang dilakukan maka dapat ditarik kesimpulan sebagai berikut :

1. Dari 15 ibu post partum yang diberi perlakuan senam nifas maka sebagian responden yang diberi perlakuan senam nifas, mengalami penurunan TFU yang cepat yaitu sebanyak 7 orang (46\%), dan sebagian lainnya mengalami penurunan TFU yang normal yaitu sebanyak 6 orang $(40 \%)$ dan sangat sedikit responden lainnya mengalami penurunan TFU yang lambat yaitu sebanyak 2 orang (14\%).

2. Dari 15 ibu post partum yang termasuk kelompok kontrol yang tidak diberi perlakuan senam nifas mengalami penurunan TFU yang cepat yaitu sebanyak 1 orang (7\%), dan sebagian kecil lain mengalami penurunan TFU yang normal yaitu sebanyak 5 orang (33\%) dan sebagian besar lainnya mengalami penurunan TFU yang lambat yaitu sebanyak 9 orang $(60 \%)$.

3. Didapatkan U hitung sebesar 40 yang lebih kecil bila dibanding $\mathrm{U}$ tabel sebesar 56 dan nilai $\mathrm{p}$ value 0.001 yang lebih kecil bila dibanding nilai $\alpha=0.05$ sehingga hipotesis di terima yaitu ada pengaruh senam nifas terhadap penurunan TFU pada ibu post partum di Wilayah Kerja Puskesmas Prabumulih Barat.

\section{Saran}

Perlu dilakukan penelitian lebih lanjut dengan mengikut sertakan faktor-faktor lain yang mempengaruhi proses involusi uterus misalnya usia, paritas, gizi dan menyusui. Diharapkan penelitian dilakukan hingga masa nifas selesai sehingga akan memperoleh hasil yang lebih optimal. Jumlah sampel dalam penelitian 
menggunakan sampel yang kecil, maka perlu adanya penelitian lebih lanjut dengan jumlah sampel yang besar sehingga dapat mewakili ibu post partum yang lebih luas.

Mengingat besarnya manfaat yang diperoleh ibu post partum, bila melaksanakan senam nifas maka diharapkan institusi pelayanan kesehatan menerapkan senam nifas sebagai asuhan pada ibu post partum. Karena berdasarkan penelitian ini terdapat pengaruh yang baik antara senam nifas dan kecepatan penurunan TFU.

\section{DAFTAR PUSTAKA}

Departemen Kesehatan Republik Indonesia.

Standar pelayanan kebidanan. Jakarta:

Depkes RI; 2005

Ipoel, 2017. Berapa Lama Pemulihan Organ

Dalam Rahim Usai Melahirkan. http://nakita.grid.id/read/027341/berapa-

lama-pemulihan-organ-dalam-rahim-usaimelahirkan-?page=all.

Rini, Susilo.2017.Panduan Asuhan Nifas dan Evidence Based Practice : Yogyakarta : Deepublish

Tapiwa M. An Evaluation of the quality of care midwives provide during the postpartum periode in Northem Botswana (Thesis). Botswana. Institute of General Practise and Community Medicine, The Faculty of Medicine. University Osla, 2001.

Oxom Harry dan William R. Forte.2010. Ilmu Kebidanan Patologi \& Fisiologi Persalinan.Yayasan Essentia Medica (YEM):Yogyakarta.

Pitriani, Risa, 2014.Panduan Lengkap Asuhan Kebidanan Ibu Nifas Normal (Askeb III).Deepublish:Yogyakarta

Varney H, Kriebs M, Gegor C. Buku Ajar Asuhan Kebidanan (Terjemahan). Volume 2 Jakarta : EGC : 2007

Nurtiati dkk, 2014.Pengaruh Senam Nifas terhadap Penurunan Tinggi Fundus Uteri Pada Ibu PostPartum di RSUP DR. M.Djamil Padang. file:///C:/Users/User/Downloads/111-221-1SM.pdf 
